\title{
HUBUNGAN MINAT BELAJAR DENGAN HASIL BELAJAR IPS SISWA KELAS IV SDN SEKECAMATAN KEBUMEN TAHUN AJARAN 2019/2020
}

\author{
Diah Monitasari, Suhartono, Joharman
}

Universitas Sebelas Maret

diahmonita@student.uns.ac.id

\section{Article History \\ accepted 01/10/2020}

approved 01/11/2020 published 01/12/2020

\begin{abstract}
Interest in learning affects student learning outcomes in learning process. Lack of students' interest in learning makes low social science learning outcomes. The study aimed to determine the positive correlation between students' interest in learning and social science learning outcomes and to determine the contribution of interest in learning to social science learning outcomes of fourth grade students of public elementary schools in Kebumen subdistrict in academic year of 2019/2020. It was quantitative research design with correlation method. The sampling method used cluster random sampling technique. The result indicated that there was positive correlation between interest in learning and social science learning outcomes with low correlation level which was 0.245 . The adjusted $R$ square value of interest in learning to social science learning outcomes was 5.96\%. It concludes that there is positive correlation between interest in learning and social science learning outcomes to fourth grade students of public elementary schools in Kebumen sub-district in academic year of 2019/2020.
\end{abstract}

Keywords: interest in learning, learning outcomes, social science

\begin{abstract}
Abstrak
Pada proses pembelajaran minat belajar memengaruhi hasil belajar siswa. Maka rendahnya hasil belajar IPS dapat dipengaruhi karena kurangnya minat belajar siswa. Tujuan penelitian ini yaitu mengetahui adanya hubungan positif antara minat belajar dan hasil belajar IPS siswa kelas IV SDN se-Kecamatan Kebumen tahun ajaran 2019/2020 dan mengetahui besarnya sumbangan minat belajar terhadap hasil belajar IPS siswa kelas IV SDN seKecamatan Kebumen tahun ajaran 2019/2020. Penelitian ini merupakan penelitian kuantitatif dengan metode korelasional. Pengambilan sampel dilakukan menggunakan teknik cluster random sampling. Hasil penelitian menunjukkan bahwa terdapat hubungan positif antara minat belajar dan hasil belajar IPS siswa kelas IV dengan tingkat korelasi rendah yaitu sebesar 0,245 . Nilai sumbangan efektif variabel minat belajar terhadap hasil belajar IPS yaitu $5,96 \%$. Berdasarkan analisis dan pembahasan hasil penelitian dapat disimpulkan bahwa terdapat hubungan yang positif antara minat belajar dan hasil belajar IPS siswa kelas IV SDN se-Kecamatan Kebumen tahun ajaran 2019/2020.
\end{abstract}

Kata kunci: minat belajar, hasil belajar, IPS 


\section{PENDAHULUAN}

Pendidikan merupakan sarana untuk manusia dalam mengembangkan potensi yang dimiliki. Proses pendidikan adalah mempersiapkan seseorang untuk hidup layak di masa depan melalaui pengajaran dan pelatihan. Berkaitan dengan proses belajar, Rusmiati (2017: 23) mengatakan bahwa belajar merupakan bukan suatu hasil atau tujuan melainkan suatu proses atau kegiatan. Sehingga belajar merupakan suatu proses untuk mencapai hasil belajar yang terlihat setelah pembelajaran berakhir. Hasil belajar adalah pencapaian bentuk perubahan perilaku atau kemampuan baik dari aspek kognitif, aspek afektif, dan aspek psikomotoris pada siswa yang didapat melalui proses belajar.

IImu Pengetahuan Sosial (IPS) merupakan bidang studi yang mempelajari masalah dan dan gejala sosial di masyarakat untuk membangun dirinya, masyarakat, bangsa, dan lingkungannya. Gunawan (2013: 18) menyatakan pembelajaran IPS bertujuan untuk membentuk warga negara yang berkemampuan sosial dan yakin akan kehidupannya sendiri ditengah-tengah kekuatan fisik maupun sosial, yang pada gilirannya akan menjadi warga negara yang baik serta bertanggung jawab.

Hasil belajar IPS yang rendah dapat dipengaruhi karena kurangnya minat belajar siswa dan anggapan bahwa IPS adalah mata pelajaran yang membosankan. Minat belajar siswa terhadap mata pelajaran IPS yang rendah terlihat ketika di kelas pada pembelajaran dengan materi IPS siswa kurang aktif dan tidak bersungguhsungguh dalam belajar. Bila siswa tidak memiliki minat dan perhatian yang besar terhadap suatu pelajaran maka sulit diharapkan siswa mendapatkan hasil yang baik pada pelajaran tersebut. Menurut Susanto (2014: 3-4) Guru yang kurang mengikutsertakan siswa dalam proses pembelajaran IPS akan membuat pembelajaran IPS tidak menarik dan terkesan membosankan. Pembelajaran IPS yang tidak menarik dan membosankan karena dianggap hanya untuk kepentingan sesaat, yang tidak ada manfaat bagi praktis dalam kehidupan sehari-hari di masyarakat.

Menurut Lestari (2015: 120) minat belajar merupakan dorongan batin yang tumbuh dari siswa untuk meningkatkan kebiasaan belajar. Minat belajar ini dapat tumbuh ketika siswa ingin memperoleh nilai terbaik atau ingin memenangkan persaingan dalam belajar dengan siswa lainnya. Minat belajar siswa yang rendah akan menimbulkan rasa bosan terhadap kegiatan pembelajaran yang berlangsung. Adanya hubungan minat belajar dengan hasil belajar sejalan dengan yang dikatakan oleh Nurhasanah \& Sobandi (2016: 133) bahwa minat belajar berpengaruh positif dan signifikan terhadap hasil belajar. Dengan demikian adanya peningkatan minat belajar pada siswa maka akan diikuti oleh peningkatan hasil belajarnya, artinya semakin naik minat belajar siswa, maka berdampak pada hasil belajar siswa yang semakin baik.

Siswa yang memiliki minat belajar yang tinggi akan mencurahkan perhatiannya pada pembelajaran yang berlangsung. Menurut Wulandari, Marhadi \& Antosa (2016: 9) menyatakan bahwa untuk meningkatkan hasil belajar siswa, salah satunya adalah menumbuhkan semangat minat belajar itu sendiri, karena dengan adanya minat belajar akan turut serta mengalami proses bagaimana memulai, melaksanakan dan mengikuti mata pelajaran IPS tersebut.

Minat tidak hanya memengaruhi tingkah laku seseorang, namun juga mendorong seseorang tetap melakukan dan memperoleh sesuatu. Kegiatan belajar siswa akan berjalan dengan lancar apabila ada minat. Ratiana (Fiana, Karsadi, dan Rifai, 2018: 243) mengungkapkan bahwa seorang siswa yang menyukai mata pelajaran IPS, maka ia akan menerima pelajaran tersebut dengan senang, terus 
menerus mempelajarinya, tidak merasa bosan dan tidak terpaksa dalam belajar IPS. Untuk meningkatkan hasil belajar siswa, salah satunya adalah dengan menumbuhkan semangat minat belajar itu sendiri. Sejalan dengan hal tersebut Budiwibowo (2016: 62) mengatakan bahwa pada kegiatan belajar minat mempunyai peranan yang sangat penting. Bila seorang siswa tidak memiliki minat dan perhatian yang besar terhadap objek yang dipelajari maka sulit diharapkan siswa tersebut akan tekun dan hasil belajar yang umumnya baik.

Minat belajar bukanlah satu-satunya faktor internal yang memengaruhi hasil belajar siswa. Masih terdapat faktor lain yang memengaruhi hasil belajar. Hamdani (2011: 139-146) menyatakan bahwa hasil belajar siswa dipengaruhi oleh faktor internal dan faktor eksternal, faktor internal yaitu kecerdasan, faktor jasmaniah, sikap, minat, bakat, dan motivasi, sedangkan faktor eksternal yaitu keadaan keluarga, keadaan sekolah, dan lingkungan masyarakat. Pada penelitian ini peneiti hanya meneliti tentang minat belajar, bagaimana hubungan minat belajar dengan hasil belajar IPS yang diperoleh siswa. Peneliti meneliti hasil belajar pada aspek kognitif. Salah satu cara mengukur hasil belajar siswa pada aspek koginitif adalah melalui tes mengenai materi pelajaran yang sudah diajarkan guru. Pada penelitian ini materi pelajaran yang digunakan adalah materi IPS. Jenjang kognitif yang diukur adalah pada jenjang C1 sampai jenjang C4.

Berdasarkan uraian di atas tujuan penelitian ini yaitu untuk mengetahui adanya hubungan positif antara minat belajar dan hasil belajar IPS siswa kelas IV SDN se-Kecamatan Kebumen tahun ajaran 2019/2020 dan mengetahui besarnya sumbangan minat belajar terhadap hasil belajar IPS siswa kelas IV SDN seKecamatan Kebumen tahun ajaran 2019/2020.

\section{METODE}

Penelitian ini merupakan penelitian kuantitatif dengan metode korelasi. Populasi penelitian ini yaitu siswa kelas IV SDN se-Kecamatan Kebumen tahun ajaran 2019/2020 sebanyak 1.554 siswa dengan sampel sebanyak 323 siswa pada 12 SDN dari 59 SDN di Kecamatan Kebumen. Teknik sampling yang digunakan adalah cluster random sampling.

Teknik pengumpulan data pada penelitian ini yaitu angket dan tes. Angket digunakan untuk pengumpulan data penelitian pada variabel minat belajar, sedangkan tes digunakan untuk mengumpulkan data pada variabel hasil belajar IPS. Pada penelitian ini dalam menganalisis uji validitas menggunakan bantuan aplikasi Statistical Product and Service (SPSS) versi 18 dan untuk menghitung reliabilitas peneliti menggunakan rumus Cronbach's Alpha.

Peneliti menggunakan aplikasi SPSS versi 18 dalam menguji hipotesis. Uji prasyarat data penelitian ini yaitu uji normalitas dan uji linieritas data. Uji normalitas data digunakan untuk mengetahui apakah data yang akan dianalisis dengan statistik parametrik berdistribusi normal. Uji normalitas menggunakan metode uji Kolmogorov Smirnov. Sedangkan uji linieritas dilakukan sebagai salah satu syarat untuk melakukan analisis korelasi data. Selanjutnya, analisis korelasi yang digunakan yaitu analisis korelasi Pearson Product Moment. Setelah melakukan analisis korelasi selanjutnya menghitung besar sumbangan efektif (SE). Sumbangan efektif merupakan sumbangan suatu variabel prediktor terhadap variabel kriterium. Sumbangan efektif pada penelitian ini menggunakan rumus menurut Winarsunu (2017) yaitu $S E=(S R) \times(K P)$. 
HASIL DAN PEMBAHASAN

Penelitian dilakukan dengan memberikan angket minat belajar dan soal tes hasil belajar IPS di SD yang menjadi sampel penelitian. Uji prasyarat data pada penelitian ini telah terpenuhi yaitu data berdistribusi normal dan data berhubungan linier.

Tabel 1. Hasil Analisis Uji Normalitas Variabel Hasil Belajar IPS

\begin{tabular}{cccc}
\hline \multicolumn{3}{c}{ Tests of Normality } \\
\hline & \multicolumn{3}{c}{ Kolmogorov-Smirnov ${ }^{\text {a }}$} \\
\cline { 2 - 4 } & Statistic & df & Sig. \\
\hline Hasil_belajar & .050 & 323 & .052 \\
\hline
\end{tabular}

Tabel 2. Hasil Analisis Uji Normalitas Variabel Minat Belajar

Tests of Normality

\begin{tabular}{crrr}
\hline & \multicolumn{3}{c}{ Kolmogorov-Smirnov } \\
\cline { 2 - 4 } & Statistic & df & Sig. \\
\hline Minat_belajar & .048 & 323 & .068 \\
\hline
\end{tabular}

Data hasil belajar IPS berdistribusi normal ditunjukkan dengan nilai signifikasi sebesar 0,052 pada tabel 1 dan data minat belajar berdistribusi normal dengan nilai signifikansi sebesar 0,068 pada tabel 2 . Nilai signifikansi pada kedua variabel tersebut menunjukkan $>0,05$ sehingga data berdistribusi normal.

Tabel 3. Hasil Uji Linieritas Data Hasil Belajar IPS dan Minat Belajar

\begin{tabular}{llcc}
\hline & & $\mathrm{F}$ & Sig. \\
\hline Hasil_belajar * & (Combined) & 1.991 & .266 \\
Minat_belajar & Linearity & 6.771 & .060 \\
& $\begin{array}{l}\text { Deviation from } \\
\text { Linearity }\end{array}$ & 1.976 & .269 \\
\hline
\end{tabular}

Data hasil belajar IPS dan data minat belajar memiliki hubungan yang linier, hal tersebut ditunjukkan dari nilai Sig. Deviation from Linearity sebesar 0,269 pada tabel 3. Nilai Sig. Deviation from Linearity $>0,05$ sehingga data hasil belajar IPS dan data minat belajar memiliki hubungan yang linier.

Data minat belajar dan hasil belajar IPS yang telah lolos uji prasyarat selanjutnya dilakukan analisis data uji hipotesis.

Tabel 4. Hasil Analisis Korelasi Minat Belajar dan Hasil Belajar IPS Correlations

\begin{tabular}{llrr}
\hline & & Hasil_belajar & Minat_belajar \\
\hline Hasil_belajar & Pearson Correlation & 1 & $.245^{* *}$ \\
& Sig. (1-tailed) & & .000 \\
& $\mathrm{~N}$ & 323 & 323 \\
Minat_belajar & Pearson Correlation & $.245^{\star *}$ & 1 \\
& Sig. (1-tailed) & .000 & \\
& $\mathrm{~N}$ & 323 & 323 \\
\hline
\end{tabular}

${ }^{\star *}$. Correlation is significant at the 0.01 level (1-tailed). 
Berdasarkan analisis yang telah dilakukan, diketahui nilai Sig. (1-tailed) yaitu 0,000 pada tabel 4. Nilai Signifikansi $0,000<0,05$, artinya hipotesis penelitian ini dapat diterima. Jadi dapat disimpulkan bahwa terdapat hubungan signifikan antara minat belajar siswa dengan hasil belajar IPS siswa kelas IV SDN se-Kecamatan Kebumen tahun ajaran 2019/2020. Hasil penelitian ini sejalan dengan hasil penelitian yang dilakukan oleh Nisa (2015: 8) yang mengungkapkan bahwa adanya pengaruh positif antara variabel minat belajar dengan hasil belajar IPS dan setiap ada kenaikan satu unit minat belajar maka diikuti dengan kenaikan hasil belajar IPS.

Hasil koefisien korelasi sebesar 0,245 menunjukkan bahwa minat belajar dan hasil belajar IPS memiliki hubungan yang positif dengan tingkat hubungan yang rendah. Pengukuran tingkat korelasi pendapat Riduwan (2019: 138) yang menyatakan nilai koefisien korelasi berkisar antara 0,20 sampai 0,399 tingkat hubungannya rendah. Hasil uji korelasi pada penelitian ini dengan tingkat hubungan yang rendah sejalan dengan hasil penelitian yang dilakukan oleh Wulandari, Marhadi \& Antosa (2016: 8) yang menyatakan bahwa terdapat hubungan positif dan signifikan antara minat belajar siswa dengan hasil belajar IPS dengan koefisien korelasinya 0,241 yang menunjukkan hubungan positif dengan tingkat hubungan yang rendah. Berdasarkan hasil penelitan bahwa minat belajar memiliki hubungan dengan hasil belajar. Oleh sebab itu, guru hendaknya membangkitkan minat siswa untuk menguasai pengetahuan yang terkandung dalam bidang studinya dengan cara yang lebih variatif dan menarik sehingga mampu meningkatkan minat siswa terhadap pelajaran dan dapat berpengaruh baik terhadap hasil belajar siswa.

Hasil perhitungan sumbangan efektif pada variabel minat belajar dan hasil belajar IPS didapatkan hasil sebesar 5,96\%, artinya minat belajar dapat berperan dalam meningkatkan hasil belajar IPS sebesar 5,96\% dan sisanya sebesar $94,04 \%$ dipengaruhi oleh faktor lain. Hasil penelitian ini sejalan dengan penelitian yang dilakukan oleh Wulandari, Marhadi \& Antosa (2016: 8) dengan hasil penelitian bahwa minat belajar memberikan kontribusi terhadap hasil belajar IPS siswa kelas IV SD Negeri Gugus III Kecamatan Rumbai, Kota Pekanbaru sebesar 5,8\% dan selebihnya $94,2 \%$ dipengaruhi variabel lain diluar variabel yang diteliti.

Minat belajar adalah salah satu faktor diantara faktor lain yang dapat memengaruhi hasil belajar, sehingga nilai sumbangan efektif variabel minat belajar yang rendah pada penelitian ini dapat disebabkan karena terdapat faktor lain yang memberikan sumbangan yang lebih besar terhadap hasil belajar seperti faktor intelegensi siswa, motivasi siswa, dan keluarga. Dasar pemilihan ketiga faktor selain minat belajar yang dapat memberikan pengaruh besar terhadap hasil belajar siswa tersebut adalah, pada faktor intelegensi memberikan sumbangan besar terhadap hasil belajar siswa karena seseorang yang memiliki inteligensi yang baik pada umumnya mudah belajar dan hasil belajarnya akan cenderung baik. Selanjutnya untuk faktor motivasi dapat memberikan pengaruh besar karena motivasi belajar yang dimiliki siswa akan membuat siswa melakukan berbagai upaya atau usaha untuk meningkatkan keberhasilan belajarnya, sehingga sangat penting siswa memiliki motivasi tinggi dalam belajar. Faktor selanjutnya yaitu keluarga, keluarga merupakan tempat tinggal siswa setelah di sekolah, keluarga inilah yang selanjutnya memberikan pendidikan dan juga peran orang tua sangat penting dalam proses belajar siswa. 
1. Intelegensi

Tingkat kecerdasan merupakan wadah yang memberikan pengaruh bagi kemungkinan tercapainya tujuan belajar yang diinginkan. Menurut Samsuri (Nursyaidah, 2014: 73) intelegensi merupakan kecakapan yang terdiri dari:

a. Kecakapan untuk menghadapi dan menyesuaikan kedalam situasi yang baru dengan cepat dan efektif.

b. Mengetahui/menggunakan konsep-konsep yang abstrak secara efektif.

c. Mengetahui relasi dan mengetahuinya dengan cepat.

Intelegensi besar pengaruhnya terhadap kemajuan belajar siswa. Menurut Nursyaidah (2014: 73) mengungkapkan bahwa dalam situasi yang sama, siswa yang mempunyai intelegensi yang tinggi akan lebih berhasil dalam belajarnya dari pada yang mempunyai tingkat intelegensi yang rendah.

2. Motivasi

Motivasi belajar yang dimiliki siswa menentukan intensitas usaha siswa dalam belajar sehingga hasil belajar siswa dapat meningkat dengan motivasi belajar yang tinggi. Menurut Sudjana (Angraini, Aminuyati, \& Achmadi, 2016: 7) "keberhasilan belajar dapat dilihat dalam motivasi yang ditunjukkan oleh para siswa pada saat melaksanakan kegiatan belajar mengajar".

Motivasi belajar yang tinggi akan membuat siswa lebih giat dan lebih semangat dalam mempelajari pelajaran tersebut. Menurut Bakar (Andriani \& Rasto, 2019: 82) motivasi belajar mempunyai peranan besar dari keberhasilan seorang siswa. Hasil belajar akan menjadi optimal jika ada motivasi belajar. Makin tepat motivasi belajar yang diberikan, akan semakin baik hasil belajar siswa.

3. Keluarga

Lingkungan keluarga dalam keadaan baik dengan anggota keluarga yang memberikan perhatian kepada siswa akan membuat siswa belajar dengan nyaman dalam keluarga tersebut, sehingga akan mendorong siswa untuk giat belajar. Menurut Jamil \& Azra (2014: 89) yang menyatakan bahwa faktor orang tua sangat besar pengaruhnya terhadap keberhasilan anak dalam belajar. Tinggi rendahnya Pendidikan orang tua, besar kecilnya pengahsilan, cukup atau kurangnya perhatian dan bimbingan orang tua, rukun atau tidaknya kedua orang tua, akrab atau tidaknya hubungan orang tua dengan anak-anak, tenang atau tidaknya situasi dalam rumah, semuanya itu turut memengaruhi pencapaian hasil belajar anak.

Minat belajar bukanlah satu-satunya faktor yang memengaruhi hasil belajar, namun berdasarkan hasil penelitian di atas menunjukkan bahwa minat belajar memiliki hubungan positif dengan hasil belajar siswa. Maka untuk meningkatkan hasil belajar siswa, salah satunya dengan menumbuhkan minat belajar siswa. Meningkatkan minat belajar siswa dapat melalui penyampaian materi oleh guru yang dilakukan dengan cara yang lebih variatif dan menarik. Jika minat ini muncul maka siswa aku bersungguhsungguh terhadap suatu pembelajaran dan senantiasa mengikuti pelajaran dengan baik. Adanya hubungan minat belajar terhadap peningkatan hasil belajar siswa hendaknya menjadi gambaran untuk sekolah dalam menciptakan lingkungan sekolah yang berkualitas dengan sarana dan prasarana yang memadai sehingga dapat memunbuhkan minat belajar siswa.

\section{SIMPULAN}

Berdasarkan hasil penelitian mengenai minat belajar dan hasil belajar IPS siswa kelas IV SDN se-Kecamatan Kebumen tahun ajaran 2019/2020 dapat diperoleh 
kesimpulan bahwa terdapat hubungan positif antara minat belajar dan hasil belajar IPS siswa kelas IV dengan nilai Sig. pada uji korelasi Pearson Product Moment yaitu 0,000 $<0,05$ ( $\alpha$ taraf $5 \%$ ). Nilai sumbangan efektif variabel minat belajar terhadap hasil belajar IPS yaitu 5,96\% dan sisanya 94,04\% dipengaruhi oleh faktor lain.

Peneliti mengajukan saran sebagai berikut: (1) Guru dapat membantu siswa dalam memicu minat belajar siswa agar menjadi lebih baik, sehingga siswa yang memiliki minat belajar yang tinggi akan mendapatkan pencapaian hasil belajar yang tinggi pula (2) Sekolah hendaknya menciptakan lingkungan belajar yang mendukung untuk meningkatkan minat belajar siswa, dan (3) Bagi peneliti yang akan meneliti variabel minat belajar siswa, penelitian ini dapat dijadikan sebagai acuan atau referensi untuk membantu dalam melakukan penelitian. Selain itu diharapkan peneliti lain dapat mengkaji lebih lanjut mengenai minat belajar serta faktor-faktor yang memengaruhi hasil belajar selain yang diteliti dalam penelitian ini.

\section{DAFTAR PUSTAKA}

Andriani, R. \& Rasto. (2019). Motivasi Belajar Sebagai Determinan Hasil Belajar Siswa. Jurnal Pendidikan Manajemen Perkantoran, 4(1), 80-86.

Angraini, W.D., Aminuyati., \& Achmadi. (2016). Analisis Faktor-faktor yang Mempengaruhi Hasil Belajar Mata Pelajaran Ekonomi Kelas XI IIS SMA. Jurnal Pendidikan dan Pembelajaran Khatulistiwa, 5(8), 1-11.

Budiwibowo, S. (2016). Hubungan Minat Belajar Siswa dengan Hasil Belajar IPS di SMP Negeri 14 Kota Madiun. Jurnal Studi Sosial, 1(1), 60-68.

Fiana, W., Karsadi., \& Rifai, N. (2018). Hubungan Minat Belajar Dan Motivasi Belajar Siswa dengan Hasil Belajar IPS Siswa SD Negeri Di Kecamatan Kendari. Jurnal Wahana Pendidikan IPS, 2(1), 242-248.

Gunawan, R. (2013). Pendidikan IPS: Filosofi, Konsep dan Aplikasi. Bandung: Alfabeta.

Hamdani. (2011). Strategi Belajar Mengajar. Bandung: Pustaka Setia.

Jamil, H. \& Azra, F.I. (2014). Pengaruh Lingkungan Keluarga dan Motivasi Belajar Siswa Terhadap Hasil Belajar Akuntansi Siswa Kelas X SMK Negeri 1 Solok Selatan. Jurnal of Economic and Economic Education, 2(2), 85-98.

Jihad, A. \& Haris, A. (2012). Evaluasi Belajar. Yogyakarta: Multi Pressindo.

Lestari, I. (2015). Pengaruh Waktu Belajar dan Minat Belajar Terhadap Hasil Belajar Matematika. Jurnal Formatif, 3(2), 115-125.

Nisa, A. (2015). Pengaruh Perhatian Orang Tua dan Minat Belajar Siswa Terhadap Prestasi Belajar IImu Pngetahuan Sosial. Jurnal IImiah Kependidikan, 2 (1), 19.

Nurhasanah, S \& Sobandi, A. (2016). Minat Belajar Sebagai Determinan Hasil Belajar Siswa. Jurnal Pendidikan Manajemen Perkantoran, 1(1), 128-135.

Susanto, A. (2014). Pengembangan Pembelajaran IPS di Sekolah Dasar. Jakarta: Prenadamedia Group.

Riduwan. (2019). Belajar Mudah Penelitian untuk Guru-Karyawan dan Peneliti Pemula. Bandung: Alfabeta.

Rusmiati. (2017). Pengaruh Minat Belajar Terhadap Prestasi Belajar Bidang Studi Ekonomi Siswa MA AI Fattah Sumbermulyo. Jurnal Pendidikan dan Ekonomi, 1(1), 21-36. 
Volume 8 Nomor 3 Tahun 2020

Wulandari, S., Marhadi, H \& Antosa, Z. (2016). Hubungan Minat Belajar dengan Hasil Belajar IPS Siswa Kelas IV SD Negeri Gugus III Kecamatan Rumbai Kota Pekanbaru. Jurnal Online Mahasiswa Fakultas Keguruan dan IImu Pendidikan Universitas Riau, 3(2), 1-11.

Winarsunu, T. (2017). Statistik dalam Penelitian Psikologi, dan Pendidikan. Malang: UMM Pres 